\title{
OUTBREAKS OF HUMAN-HERPES VIRUS 6 (HHV-6) INFECTION IN DAY-CARE CENTERS IN BELÉM, PARÁ, BRAZIL
}

\author{
Ronaldo B. FREITAS(1), Talita A.F. MONTEIRO(1) \& Alexandre C. LINHARES(1)
}

\begin{abstract}
SUMMARY
A total of 730 children aged less than 7 years, attending 8 day-care centers (DCCs) in Belém, Brazil were followed-up from January to December 1997 to investigate the occurrence of human-herpes virus 6 (HHV-6) infection in these institutional settings. Between October and December 1997 there have been outbreaks of a febrile- and -exanthematous disease, affecting at least 15-20\% of children in each of the DCCs. Both serum- and- plasma samples were obtained from 401 (55\%) of the 730 participating children for the detection of HHV-6 antibodies by enzyme-linked immunosorbent assay (ELISA), and viral DNA amplification through the nested-PCR. Recent HHV-6 infection was diagnosed in 63.8\% (256/401) of them, as defined by the presence of both IgM and IgGspecific antibodies (IgM+/IgG+); of these, $114(44.5 \%)$ were symptomatic and $142(55.5 \%)$ had no symptoms ( $\mathrm{p}=0.03)$. A subgroup of $123(30.7 \%)$ children were found to be IgM-/IgG+, whereas the remaining $22(5.5 \%)$ children had neither IgM nor IgG HHV-6antibodies (IgM-/IgG-). Of the 118 children reacting strongly IgM-positive ( $\geq 30$ PANBIO units), 26 (22.0\%) were found to harbour the HHV-6 DNA, as demonstrated by nested-PCR. Taken the ELISA-IgM- and- nested PCR-positive results together, HHV-6 infection was shown to have occurred in 5 of the 8 DCCs under follow-up. Serological evidence of recent infections by Epstein-Barr virus (EBV) and parvovirus B19 were identified in 2.0\% (8/401) and 1.5\% (6/401) of the children, respectively. Our data provide strong evidence that HHV-6 is a common cause of outbreaks of febrile/exanthematous diseases among children attending DCCs in the Belém area.
\end{abstract}

KEYWORDS: Herpesvirus type 6; Outbreaks; Day-care centers.

\section{INTRODUCTION}

The human herpesvirus type-6 (HHV-6) was first isolated in 1986, by SALAHUDDIN et $a l .{ }^{45}$, from lymphocytes of patients with lymphoproliferative disorders or acquired immunodeficiency syndrome. Although in vivo viral replication occurs mainly in $\mathrm{CD}_{4}^{+} \mathrm{T}$ lymphocytes ${ }^{19,36}$, a number of other cell lines were shown to be susceptible to HHV-6 infection ${ }^{35,40}$. In addition, HHV-6 may induce clear cytopathogenic effect when infecting lymphocyte cultures in vitro ${ }^{40,50}$.

Seroepidemiological studies conducted in several countries throughout the world provided evidence that HHV-6 infection occurs both in infants and adults, as suggested by prevalence rates of antibodies that vary from $45 \%$ to $63 \%$ and $52 \%$ to $97 \%$, respectively $1,6,24,37,42,46$. An additional finding from serosurvey studies is that infants become infected very early in life, in general before the age of 3 years ${ }^{6,37,53}$. Two HHV-6 variants (A and B) have been identified to date. While HHV-6B variant accounts mostly for cases of exanthem subitum (ES) and other less common clinical presentations among infants ${ }^{13,42,43}$, a role has not yet been firmly established for HHV-6A as a human pathogen ${ }^{47}$. In Japan,
$60 \%$ of children who have HHV-6 primary infection develop typical $\mathrm{ES}^{30}$. In contrast, about $70 \%$ of primoinfections among infants in the USA and Europe are characterized by a mild febrile illness that courses with or without exanthem ${ }^{42,43}$. A variety of other clinical conditions have also been associated with HHV-6 infections namely mononucleosis-like syndrome, sarcoidosis, hepatitis and febrile convulsion ${ }^{1,5,14,25,27,28,34}$.

The first studies dealing with HHV-6 infection in Brazil were carried out by LINHARES et al. ${ }^{33}$, who recorded seroprevalence rates of $76.5 \%$ and $77.2 \%$ in Brazilian and Japanese immigrants, respectively, in the north-eastern region. Subsequent serosurvey studies conducted in the Amazon region of Brazil yielded prevalence rates of HHV-6 antibody that ranged from $5.4 \%$ to $14.9 \%$, among amerindians ${ }^{16}$, and from $75 \%$ to $100 \%$ in the urban communities ${ }^{17}$. Furthermore, the occurrence of ES in Brazil in association with HHV-6 infection was first reported on both clinical and laboratorial grounds, by FREITAS et al ${ }^{18}$.

Worldwide, there have been few reports on outbreaks caused by HHV-6. Both serological and clinical data indicate that extensive outbreaks (mostly of ES) occurred in hospitals, London, $\mathrm{UK}^{23}$, and in

(1) Serviço de Virologia Geral, Instituto Evandro Chagas, Fundação Nacional de Saúde, Ministério da Saúde, Belém, Pará, Brasil.

Correspondence to: Dr. Ronaldo B. Freitas, Instituto Evandro Chagas, Av. Almirante Barroso 492, 66090-000 Belém, Pará, Brasil, e-mail: ronaldo@ iec.pa.gov.br. 
an orphanage, Osaka, Japan ${ }^{39}$, with incidence rates of HHV-6 infection ranging from $20 \%$ to $100 \%$. These were explosive epidemics that occurred during the summer months, affecting both children and adults, and the emergence of cases followed in general a short incubation period. In Brazil, outbreaks due to HHV-6 infection have not so far been reported.

The present report describes the occurrence of outbreaks associated with HHV-6 infection affecting children who attended several day-care centers in the urban area of Belém, Brazil.

\section{MATERIALS AND METHODS}

The present surveillance was conducted between January and December 1997 and involved 8 community DCCs which were located in 4 neighborhoods (Cremação, Guamá, Jurunas and Terra-Firme) of Belém, northern Brazil. Six of these DCCs (Alcindo Cacela, Caraparu, Monte Alegre, Santa Rosa, São Domingos and São Silvestre) belonged to the municipality's official primary school system, whereas 2 of them (Boa Esperança and Orquídea) were settled through the neighborhoods' community leadership. DCCs included in general 1-4 rooms for 30-40 children each. These children stay at the DCCs for about 11 hours $(7 \mathrm{am}$ to $6 \mathrm{pm}$ ) per day, from Monday to Friday. Apart from primary teaching, playroom activities and feeding are planned. Families seeking for these day-care facilities are mostly from the low socioeconomic level.

Overall, 730 children of both sexes were attending the 8 DCCs when the present surveillance was carried out. Each DCC housed between 40 and 130 children whose ages ranged from 1 to 7 years (mean age, 3.5 years).

From January to December 1997 regular weekly visits were made to each DCC by a trained field-worker from our staff, primarily to assess the occurrence of outbreaks of febrile/exanthematous disease in these institutional settings. Between October and December 1997 outbreaks of fever (either with or without exanthem) were recorded in all DCCs, lasting an average of 10-15 days and affecting at least $20 \%$ of the whole number of children lodged in each of them. During this period, 401 blood samples (one per child) were obtained through antecubital venepuncture, corresponding to approximately $50 \%$ of all children per DCC. Sera were kept frozen at $-20^{\circ} \mathrm{C}$ until being tested for the presence of both IgM and IgG antibodies to HHV-6 using a commercial enzymelinked immunosorbent assay (ELISA) developed by PANBIO ${ }^{\mathrm{TM}}$ (East Brisbane, Australia). This is an assay that includes a solid-phase multiwells system coated with HHV-6-infected cells, as previously described $^{4,11,41}$. For the determination of HHV-6 immunoglobulin M (IgM) sera were tested at single 1:100 (v/v) dilutions, with previous removal of IgG. This eliminates interference by HHV-6 IgG and IgM rheumatoid factor. All serum samples yielding optical density (OD) values of greater than twice of the mean absorbance of the "cut off" were regarded as suggestive of recent HHV-6 infection; this corresponds to > 20 IgM PANBIO units. An aliquot of the plasma samples was used for separation of peripheral blood mononuclear cells (PBMCs) by centrifugation through Ficoll-Hypaque gradient (Pharmacia ${ }^{\mathrm{TM}}$, Uppsala, Sweden), as described before ${ }^{50}$. The detection of HHV-6 DNA was performed by polymerase chain reaction (PCR) in both the whole plasma sample and PBMCs which were kept frozen $\left(-70^{\circ} \mathrm{C}\right)$ until being assayed. Only IgM-positive serum samples yielding $\geq 30$ PANBIO units $(\mathrm{n}=$ 118) were subjected to PCR assay. This was performed in two steps, essentially as reported before ${ }^{26,48,49}$. First amplification was carried out using a mixture of external oligonucleotide primers designated as EXI and $E X 2$, followed by a second amplification (the nested PCR) including a mixture of internal primers IN3 and IN4.

Conventional ELISA was used for the detection of both IgM and IgG to measles, rubella, parvovirus B19, Epstein-Barr virus and cytomegalovirus, as previously reported ${ }^{2,9,12,31,44}$. Samples were also tested by haemagglutination-inhibition (HI) assay ${ }^{22}$ for the determination of antibodies to Mayaro, Oropouche and dengue viruses, which are wellknown viral agents of exanthematous illnesses in the Amazon region. In addition, a immunofluorescence indirect assay (Kit Chemicon ${ }^{\mathrm{TM}}$ International, Temecula, CA, USA) was used for diagnosis of respiratory viruses in a subgroup of 40 symptomatic children such as adenovirus, influenza, parainfluenza and respiratory syncitial virus.

The present survey covered a representative sample of the population and data were analyzed using the EPI INFO software, version 6.0 (Atlanta, GA, USA). Rates were compared by using the Mantel-Haenszel chi square test of association or Fisher's exact test, as appropriate. Significance was defined as $\mathrm{p}<0.05$.

\section{RESULTS}

Overall, 730 children were enrolled to participate in this follow-up study. Both serum- and- plasma samples were obtained from 401 (55.0\%) of them and tested for the presence of HHV-6 antibodies. Table 1 shows that: (i) an $\operatorname{IgM}+/ \operatorname{IgG}+$ seroresponse was noted in $256(63.8 \%)$ of the children; (ii) previous HHV-6 infection was identified in $123(30.7 \%)$ children who reacted IgM-/IgG+; and (iii) 22 had neither IgG nor IgM antibodies to HHV-6 (IgM-/IgG-). The distribution of IgM seropositivity, according to the DCC and sex, is demonstrated in Table 2 . The prevalence rates ranged from $54.3 \%$ (DCC Orquídea) to $76.0 \%$ (Caraparu). Serological evidence of recent infection by HHV-6 occurred in $68.6 \%$ and $59.4 \%$ of female and male children, respectively. In the former group, IgM-seropositivity rates ranged from $65.5 \%$ to $71.4 \%$ for $4-5$ and $<3$ year-old groups, respectively; in the latter one, range was of $50.0 \%$ to $68.0 \%$ for the $<3$ and 3-4 year-old groups, respectively.

The results of the nested-PCR are gathered in Table 3 and in Figure 1. The viral DNA was detected in $26(22.0 \%)$ out of the 118 children selected for testing, that is, those yielding HHV-6-IgM positivity values of $\geq 30$ PANBIO units. Among these nested- PCR-positive children, 15 were male. Figure 1 illustrates the nested-PCR amplified products obtained from PBMCs of children attending 5 (63.3\%) of the 8 DCCs under investigation. Nested-PCR results were similar when testing both plasma and PBMC samples.

The clinical status of the 256 children with serological evidence of current/recent HHV-6 infection (HHV-6 IgM PANBIO units of greater than 20) is specified in Table 4. There were 114 (44.5\%) and $142(55.5 \%)$ symptomatic and asymptomatic infections, respectively $(\mathrm{p}=0.03)$. The most frequent presentation (89 children, 34.8\%) included fever $\left(\geq 39.0{ }^{\circ} \mathrm{C}\right.$ ) and respiratory symptoms (productive cough and running nose). Less frequently, the following clinical pictures could be recorded, as follows: high fever only that lasted 3-4 days, 17 children ( $6.6 \%$ ); maculo-papular exanthematous illness (MPEI), 6 (2.2\%); fever and MPEI, $1(0.4 \%)$; and fever, convulsions and watery diarrhoea, $1(0.4 \%)$. 


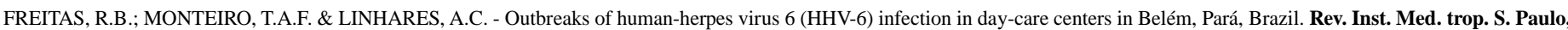
42(6):305-311, 2000.

Table 1

Detection of antibodies to HHV-6 in children of eight DCCs*, according to sex. Belém, Pará, Brazil

\begin{tabular}{|c|c|c|c|c|c|c|c|}
\hline \multirow{2}{*}{$\begin{array}{l}\text { Neighborhood/ } \\
\text { DCC }\end{array}$} & \multirow{2}{*}{$\begin{array}{l}\text { Month of } \\
\text { epidemics } \\
(1997)\end{array}$} & \multirow[t]{2}{*}{ Sex } & \multirow{2}{*}{$\begin{array}{l}\text { Total of } \\
\text { children }\end{array}$} & \multirow{2}{*}{$\begin{array}{l}\text { Total of children } \\
\text { with serum } \\
\text { samples }(\%)\end{array}$} & \multicolumn{3}{|c|}{ Serological status } \\
\hline & & & & & $(\mathrm{IgM}+/ \mathrm{IgG}+)$ & (IgM-/IgG+) & (IgM-/IgG-) \\
\hline \multicolumn{8}{|l|}{ Cremação } \\
\hline Alcindo Cacela & October & $\begin{array}{l}\text { Female } \\
\text { Male }\end{array}$ & $\begin{array}{l}57 \\
43\end{array}$ & $\begin{array}{l}33(58.0) \\
25(58.1)\end{array}$ & $\begin{array}{l}22(66.7) \\
11(42.3)\end{array}$ & $\begin{array}{r}9(27.2) \\
10(40.0)\end{array}$ & $\begin{array}{l}1(3.0) \\
4(16.0)\end{array}$ \\
\hline \multicolumn{8}{|l|}{ Guamá } \\
\hline Caraparu & November & $\begin{array}{l}\text { Female } \\
\text { Male }\end{array}$ & $\begin{array}{l}18 \\
22\end{array}$ & $\begin{array}{l}11(61.1) \\
14(63.6)\end{array}$ & $\begin{array}{r}9(81.8) \\
10(71.4)\end{array}$ & $\begin{array}{l}1(9.1) \\
4(28.6)\end{array}$ & $\begin{array}{l}1(9.1) \\
0(0)\end{array}$ \\
\hline Santa Rosa & November & $\begin{array}{l}\text { Female } \\
\text { Male }\end{array}$ & $\begin{array}{l}51 \\
49\end{array}$ & $\begin{array}{l}32(62.7) \\
31(63.3)\end{array}$ & $\begin{array}{l}24(75.0) \\
19(61.3)\end{array}$ & $\begin{array}{r}8(25.0) \\
10(32.3)\end{array}$ & $\begin{array}{l}0(0) \\
2(6.4)\end{array}$ \\
\hline \multicolumn{8}{|l|}{ Jurunas } \\
\hline Monte Alegre & December & $\begin{array}{l}\text { Female } \\
\text { Male }\end{array}$ & $\begin{array}{l}69 \\
61\end{array}$ & $\begin{array}{l}37(53.6) \\
33(54.1)\end{array}$ & $\begin{array}{l}27(72.9) \\
22(66.7)\end{array}$ & $\begin{array}{r}7(18.9) \\
11(33.3)\end{array}$ & $\begin{array}{l}3(8.1) \\
0(0)\end{array}$ \\
\hline São Silvestre & December & $\begin{array}{l}\text { Female } \\
\text { Male }\end{array}$ & $\begin{array}{l}52 \\
78\end{array}$ & $\begin{array}{l}29(55.8) \\
43(55.1)\end{array}$ & $\begin{array}{l}16(55.2) \\
26(60.5)\end{array}$ & $\begin{array}{r}9(31.0) \\
16(37.2)\end{array}$ & $\begin{array}{l}4(13.8) \\
1(2.3)\end{array}$ \\
\hline \multicolumn{8}{|l|}{ Terra Firme } \\
\hline Boa Esperança & October & $\begin{array}{l}\text { Female } \\
\text { Male }\end{array}$ & $\begin{array}{l}37 \\
43\end{array}$ & $\begin{array}{l}18(49.0) \\
21(49.0)\end{array}$ & $\begin{array}{l}11(61.1) \\
13(61.9)\end{array}$ & $\begin{array}{l}6(33.3) \\
8(38.1)\end{array}$ & $\begin{array}{l}1(5.5) \\
0(0)\end{array}$ \\
\hline Orquídea & October & $\begin{array}{l}\text { Female } \\
\text { Male }\end{array}$ & $\begin{array}{l}36 \\
34\end{array}$ & $\begin{array}{l}18(50.0) \\
17(50.0)\end{array}$ & $\begin{array}{r}11(61.1) \\
8(47.1)\end{array}$ & $\begin{array}{l}6(33.3) \\
9(52.9)\end{array}$ & $\begin{array}{l}1(5.6) \\
0(0)\end{array}$ \\
\hline São Domingos & November & $\begin{array}{l}\text { Female } \\
\text { Male }\end{array}$ & $\begin{array}{l}41 \\
39\end{array}$ & $\begin{array}{l}19(46.3) \\
20(51.3)\end{array}$ & $\begin{array}{l}13(68.4) \\
14(70.0)\end{array}$ & $\begin{array}{l}5(26.3) \\
4(20.0)\end{array}$ & $\begin{array}{l}1(5.3) \\
2(10.0)\end{array}$ \\
\hline Subtotal & & $\begin{array}{l}\text { Female } \\
\text { Male }\end{array}$ & $\begin{array}{l}361 \\
369\end{array}$ & $\begin{array}{l}197(54.6) \\
204(55.3)\end{array}$ & $\begin{array}{l}133(68.6) \\
123(60.2)\end{array}$ & $\begin{array}{l}53(26.9) \\
70(34.3)\end{array}$ & $\begin{array}{l}11(5.6) \\
11(5.4)\end{array}$ \\
\hline Total & & & 730 & $401(55.0)$ & $256(63.8)$ & $123(30.7)$ & $22(5.5)$ \\
\hline
\end{tabular}

* Day-care centers

Table 2

Distribution of recent HHV-6 infections* according to sex and age in children of eight DCCs** located in the urban area of Belém, Pará, Brazil

\begin{tabular}{|c|c|c|c|c|c|c|c|c|c|}
\hline \multirow{3}{*}{$\begin{array}{l}\text { Sex/age } \\
\text { (years) }\end{array}$} & \multicolumn{8}{|c|}{ Positive/No. tested (\%) for neighborhoods and DCCs } & \multirow{3}{*}{ Total } \\
\hline & \multirow{2}{*}{$\frac{\text { Cremação }}{\text { Alcindo Cacela }}$} & \multicolumn{2}{|c|}{ Guamá } & \multicolumn{2}{|c|}{ Jurunas } & \multicolumn{3}{|c|}{ Terra Firme } & \\
\hline & & Caraparu & Santa Rosa & Monte Alegre & São Silvestre & Boa Esperança & Orquídea & São Domingos & \\
\hline \multicolumn{10}{|l|}{ Female } \\
\hline$<3$ & $17 / 21(80.9)$ & $0 / 0(0)$ & $3 / 3(100.0)$ & $4 / 6(66.7)$ & $0 / 4(0)$ & $2 / 3(66.7)$ & $2 / 3(66.7)$ & $2 / 2(100.0)$ & $30 / 42(71.4)$ \\
\hline $3-4$ & $1 / 3(33.3)$ & $3 / 3(100.0)$ & $4 / 5(80.0)$ & $9 / 13(69.2)$ & $3 / 5(60.0)$ & $0 / 3(0)$ & $4 / 4(100.0)$ & $5 / 5(100.0)$ & $29 / 41(70.7)$ \\
\hline $4-5$ & $1 / 3(33.3)$ & $3 / 4(75.0)$ & $4 / 6(66.7)$ & $9 / 11(81.8)$ & $10 / 17(58.8)$ & $5 / 5(100.0)$ & $1 / 4(25.0)$ & $3 / 5(60.0)$ & $36 / 55(65.5)$ \\
\hline$>5$ & $3 / 5(60.0)$ & $3 / 4(75.0)$ & $13 / 18(72.2)$ & $5 / 6(83.3)$ & $3 / 3(100.0)$ & $4 / 6(66.7)$ & $57.1)$ & $3 / 7$ & $38 / 56$ \\
\hline $\begin{array}{l}\text { Subtotal } \\
\text { Male }\end{array}$ & $22 / 32(68.8)$ & $9 / 11(81.8)$ & $24 / 32(75.0)$ & $27 / 36(75.0)$ & $16 / 29(55.2)$ & $11 / 17(64.7)$ & $10 / 18$ & $13 / 19$ & $133 / 194(68.6)$ \\
\hline$<3$ & $7 / 17$ & & $2 / 3$ & 00.0) & $6 / 12$ & & & & $21 / 42(50.0)$ \\
\hline $3-4$ & $3 / 6(50.0)$ & $2 / 2(100.0)$ & $8 / 9(88.9)$ & $5 / 10(50.0)$ & $6 / 7(85.7)$ & $4 / 6(66.7)$ & $2 / 4(50.0)$ & $4 / 6(66.7)$ & $34 / 50(68.0)$ \\
\hline $4-5$ & $0 / 1(0)$ & $5 / 9(55.6)$ & $3 / 10(30.0)$ & $10 / 16(62.5)$ & $10 / 14(71.4)$ & $1 / 5(20.0)$ & $5 / 10(50.0)$ & $5 / 5(100.0)$ & $39 / 70(55.7)$ \\
\hline$>5$ & $1 / 2(50.0)$ & $3 / 3(100.0)$ & $6 / 9(66.7)$ & $4 / 6(66.7)$ & $5 / 10(50.0)$ & $7 / 8(87.5)$ & $1 / 3(33.3)$ & $2 / 4(50.0)$ & $29 / 45(64.4)$ \\
\hline Subtotal & $11 / 26(42.3)$ & $10 / 14(71.4)$ & $19 / 31(61.3)$ & $22 / 34(64.7)$ & $26 / 43(60.5)$ & $13 / 22(59.1)$ & $8 / 17(47.1)$ & $14 / 20(70.0)$ & $123 / 207(59.4)$ \\
\hline Total & $33 / 58(56.9)$ & $19 / 25(76.0)$ & $43 / 63(68.3)$ & $49 / 70(70.0)$ & $42 / 72(58.3)$ & $24 / 39(61.5)$ & $19 / 35(54.3)$ & $27 / 39(69.2)$ & $256 / 401(63.8)$ \\
\hline
\end{tabular}

\footnotetext{
* IgM detection (>20 PANBIO units); **Day-carecenters
} 


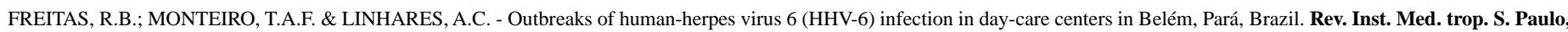
42(6):305-311, 2000.

Table 3

Detection of HHV-6 DNA in cases of recent infection* in a subgroup $(\mathrm{n}=118)$ of children attending eight DCCs**, according to sex. Belém, Pará, Brazil

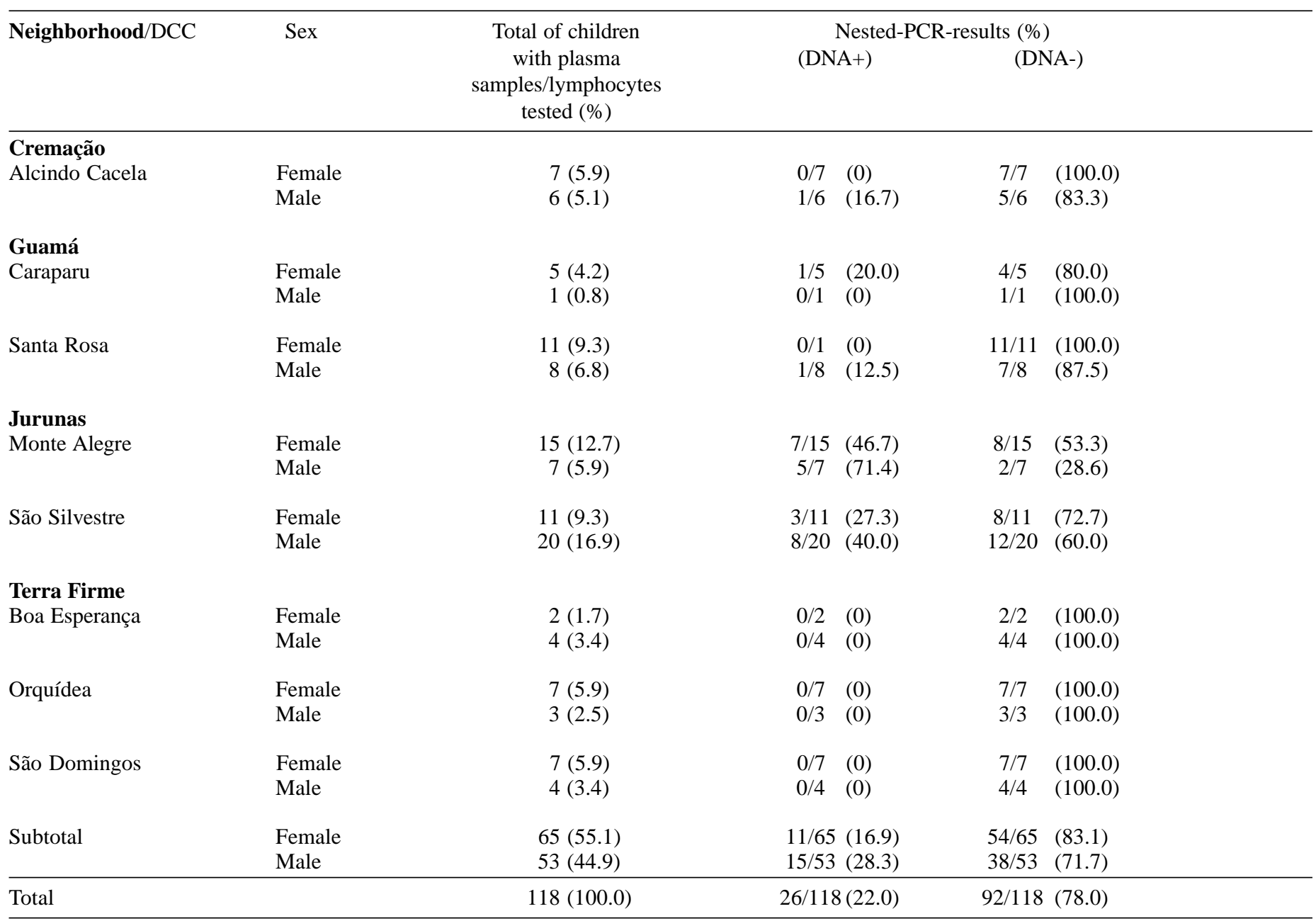

* IgM detection ( $\geq 30$ PANBIO units); **Day-care centers

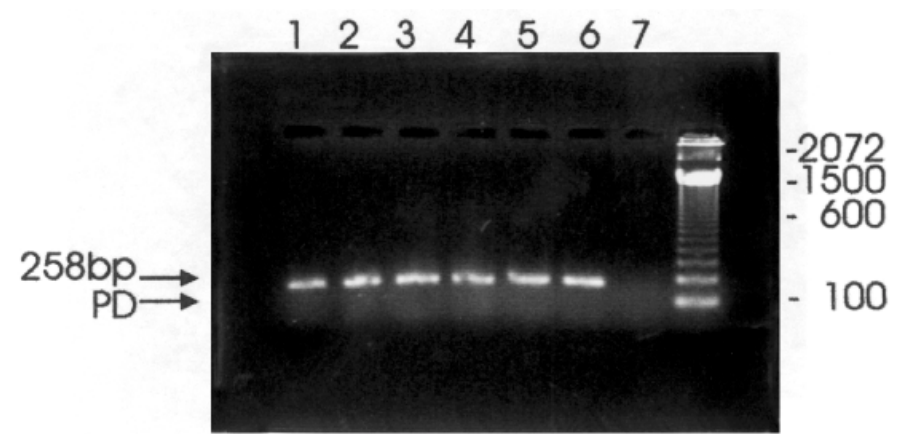

$M$

Fig. 1 - Agarose gel electrophoresis of nested PCR-amplified HHV-6 DNA of 7 plasma samples/lymphocytes, stained with ethidium bromide and photographed under U.V light. Lanes 1-5, HHV-6-positive specimens (DCCs: A. Cacela (1), Caraparu (2), S. Rosa (3), M. Alegre (4), S. Silvestre (5); lane 6, positive control; lane 7, negative control ; M denotes molecular-weight; PD denotes primer dimer.
Eight $(2.0 \%)$ of the 401 children whose sera were taken reacted $\operatorname{IgM} /$ IgG-positive for EBV, whereas 6 (1.5\%) developed parvovirus B-19 infection. These 14 children had no recent/current HHV-6 infection. No positive results indicative of recent infection were obtained from testing of sera against other pathogens that might be involved in the aetiology of the febrile and/or exanthematous illnesses. There have been no cases of current/recent dengue infection, even though an extensive outbreak was occurring in Belém.

\section{DISCUSSION}

Outbreaks of HHV-6 infection sometimes are observed among infants living in institutions, such as hospitals and orphanages, since the transmission is enhanced as a result of close contact between these institutional inmates ${ }^{23,39}$. An environment similar to these settings was noted in the present investigation - the DCCs -, where children were kept in close contact during 10-12 hours per day, therefore making outbreaks more likely to occur. 
Table 4

Clinical presentations associated with HHV-6 infection* in children of eight DCCs.** Belém, Pará, Brazil

\begin{tabular}{|c|c|c|c|c|c|c|c|}
\hline \multirow[b]{2}{*}{ Neighborhood/DCC } & \multicolumn{5}{|c|}{ Symptoms (\%) } & \multirow[b]{2}{*}{ Asymptomatic } & \multirow[b]{2}{*}{ Total } \\
\hline & Fever*** & $\begin{array}{c}\text { Fever + } \\
\text { ARI**** }\end{array}$ & Exanthem & $\begin{array}{c}\text { Fever+ } \\
\text { exanthem }\end{array}$ & $\begin{array}{c}\text { Fever+convulsion+ } \\
\text { diarrhoea }\end{array}$ & & \\
\hline \multicolumn{8}{|l|}{ Cremação } \\
\hline Alcindo Cacela & $2(0.8)$ & $11(4.3)$ & $3(1.1)$ & $1(0.4)$ & $1(0.4)$ & $18(7.0)$ & $36(14.1)$ \\
\hline \multicolumn{8}{|l|}{ Guamá } \\
\hline Caraparu & $1(0.4)$ & $4(1.6)$ & $0(0)$ & $0(0)$ & $0(0)$ & $15(5.8)$ & $20(7.8)$ \\
\hline Santa Rosa & $4(1.6)$ & $17(6.6)$ & $3(1.1)$ & $0(0)$ & $0(0)$ & $14(5.5)$ & $38(14.8)$ \\
\hline \multicolumn{8}{|l|}{ Jurunas } \\
\hline Monte Alegre & $0(0)$ & $20(7.8)$ & $0(0)$ & $0(0)$ & $0(0)$ & $32(12.5)$ & $52(20.3)$ \\
\hline São Silvestre & $0(0)$ & $15(5.8)$ & $0(0)$ & $0(0)$ & $0(0)$ & $13(5.1)$ & $28(11.0)$ \\
\hline \multicolumn{8}{|l|}{ Terra Firme } \\
\hline Boa Esperança & $2(0.8)$ & $4(1.6)$ & $0(0)$ & $0(0)$ & $0(0)$ & $22(8.6)$ & $28(11.0)$ \\
\hline Orquídea & $5(1.9)$ & $4(1.6)$ & $0(0)$ & $0(0)$ & $0(0)$ & $14(5.5)$ & $23(9.0)$ \\
\hline São Domingos & $3(1.1)$ & $14(5.5)$ & $0(0)$ & $0(0)$ & $0(0)$ & $14(5.5)$ & $31(12.1)$ \\
\hline Total & $17(6.6)$ & $89(34.8)$ & $6(2.2)$ & $1(0.4)$ & $1(0.4)$ & $142(55.5)$ & $256(100.0)$ \\
\hline
\end{tabular}

* IgM detection (> 20 PANBIO units); ** Day-care centers; $* * * 39{ }^{\circ} \mathrm{C} ; * * * *$ Acute respiratory infection.

Previous studies carried out in temperate countries (eg. England and Japan) have shown the seasonality of epidemics of HHV-6 infection, usually occurring during the summer months ${ }^{23,39}$. The fact that the presently described outbreaks have clustered during October-December, suggests a possible seasonal pattern of HHV-6 infection in our region.

The explosive nature of the outbreaks in DCCs in Belém, together with a significant proportion of children reacting HHV-6 IgM-positive, indicates the high degree of susceptibility among these institutional inmates to a highly transmissible viral agent ${ }^{23,39}$.

The gender distribution of seropositivity rates shows no significant differences, as already demonstrated in previous serosurveys conducted in the same setting ${ }^{17}$. Moreover, the predominance of recent infection by HHV-6 in the lowest age-groups ( $<3$ and 3 to 4 years) sustains previous seroepidemiological data indicating that HHV-6 infections is largely more frequent before 3 years of life ${ }^{3,7,53,54}$. In the present study it is most likely that transmission of HHV-6 had occurred by respiratory droplet infection, resulting in a high number of cases during a short time-interval. This mode of transmission has been supported by several investigations recording the detection of HHV-6 DNA in both saliva and salivary glands $\mathrm{s}^{10,15,20,21,29,32}$

In our study HHV-6 infection was significantly more likely to be asymptomatic $(\mathrm{p}=0.03)$, suggesting that exanthem subitum may not be the predominant outcome of early, primary infection in Belém. It is of interest in this regard to mention the seroepidemiological data from TAKAHASHI et al. ${ }^{51}$ suggesting that a significant proportion of children may develop HHV-6 symptomless (primary) infection later in life, therefore without having had exanthem subitum (ES).

The detection of specific-IgM in plasma samples from several children, together with the fact that HHV-6 DNA was detected in both plasma and lymphocytes of 26 individuals, suggests that primary infection was largely occurring during the outbreaks in the DCCs in Belém. It should be pointed out that the detection of viral DNA in serum/plasma samples represents a surrogate marker for HHV-6 active infection, mostly in cases of $\mathrm{ES}^{49}$. The detection of HHV-6 DNA in 5 of the 8 DCCs in Belém represents an additional evidence that HHV-6 has widely circulated among infants and children (both sexes and several age-groups) during the presently reported outbreaks. It is likely that the nested-PCR-negative results yielded in 92 patients reflect a late sample collection in the course of infection.

Of particular interest in the present survey was the occurrence of a variety of clinical conditions not resembling those related to the typical ES. This is in accordance with previous findings in USA where only $9 \%$ of patients with HHV-6 primary infection developed the typical ES ${ }^{43}$. Atypical clinical presentations have been identified in several patients, as follows: (i) exanthem without fever; (ii) acute respiratory symptoms (sore throat, productive cough and running nose) in the absence of cutaneous rash; (iii) watery diarrhoea; and (iv) febrile convulsion. Such unusual clinical presentations of HHV-6 infection early in life have also been identified in previous similar studies ${ }^{34,43}$. It should be pointed out that all illnesses in the present study coursed without any prominent complication or sequelae, as usually observed elsewhere ${ }^{37,52,53,54}$. The limited number of children presenting with convulsion may reflect the low neurotropic potential of the infecting HHV-6 strain ${ }^{8}$.

With the exception of $14(3.5 \%)$ children reacting IgM-positive for Epstein-Barr virus $(E B V)(n=8)$ and parvovirus B19 $(n=6)$, negative results were yielded when testing sera for antibodies to a variety of other pathogens that might be related to febrile/exanthematous disease in our region. Of note, the possible role of adenoviruses, influenza, parainfluenza and respiratory syncytial virus in the aetiology of respiratory illnesses was also ruled out. 
Local studies are currently being planned to assess the genotypic diversity of HHV-6 strains, in view of the apparently broad clinical spectrum of the disease in our region.

\section{RESUMO}

\section{Surtos epidêmicos associados à infecção pelo herpesvírus tipo 6 (HHV-6) em creches comunitárias de Belém, Pará, Brasil}

Um total de 730 crianças com menos de 7 anos de idade, matriculadas em oito creches comunitárias (CCS) em Belém, Brasil foi acompanhado de janeiro a dezembro de 1997, com objetivo de se investigar a ocorrência de epidemias de infecção pelo HHV-6. Entre os meses de outubro e dezembro de 1997 foram registrados surtos de doença febrilexantemática acometendo cerca de $15-20 \%$ da população de cada CC. Amostras de soro e plasma foram obtidas de $401(55,0 \%)$ das 730 crianças participantes, tendo como finalidade a detecção de anticorpos para o HHV-6 e amplificação do DNA viral, utilizando-se o método imunoenzimático (ELISA) e as provas de biologia molecular: reação em cadeia da polimerase (PCR) nested PCR. Infecção recente para o HHV-6 foi diagnosticada em 63,8\% (256/401) das crianças, as quais, apresentaram anticorpos $\operatorname{IgM}$ e $\operatorname{IgG}(\mathrm{IgM}+/ \mathrm{IgG}+)$. Dessas, 114 (44,5\%) foram sintomáticas e $142(55,5 \%)$ assintomáticas $(\mathrm{p}=0,03)$. Um subgrupo de $123(30,7 \%)$ menores foi identificado como previamente imune (IgM$/ \mathrm{IgG}+)$ e $22(5,5 \%)$ crianças não apresentaram anticorpos $\operatorname{IgM}$ e $\mathrm{IgG}$ (IgM-/IgG-). O DNA do HHV-6 foi detectado em 26 (22,0\%) das 118 crianças selecionadas, apresentando resultados expressivos quanto à detecção de anticorpos $\operatorname{IgM}$ ( $\geq 30$ unidades PANBIO). Os resultados obtidos no ELISA e nested PCR comprovaram a ocorrência de infecção recente em 5 das 8 CCs sob acompanhamento. Evidência sorológica de infecção recente para o vírus de Epstein-Barr (EBV) e parvovírus B19 foi identificada em 2,0\% (8/401) e 1,5\% (6/401) das crianças, respectivamente. Nossos resultados demonstram uma expressiva evidência de que o HHV-6é uma causa comum de epidemias relacionadas a doença febril-exantemática em crianças matriculadas nas CCs da área urbana de Belém.

\section{ACKNOWLEDGMENTS}

We thank Dr. Elisabeth O. Santos and Dr. Amélia Travassos da Rosa for carrying out the serological tests for measles, rubella, cytomegalovirus infection and Mayaro, Oroupoche and dengue viruses, respectively. We are also grateful to Dr. Rosa Helena P. Gusmão for providing clinical support. Thanks are also due Mrs. Edna A. Filizzola and Mrs. Maria Joana da Costa for technical and logistical support.

\section{REFERENCES}

1. ABLASHI, D.V.; JOSEPHS, S.F.; BUCHBINDER, K. et al. - Human B-lymphotropic virus (human herpesvirus-6). J. virol. Meth., 21: 29-48, 1988.

2. ANDERSON, L.J.; TSOU, C.; PARKER, R.A. et al. - Detection of antibodies and antigens of human parvovirus B19 by enzyme-linked immunosorbent assay. J. clin. Microbiol., 24: 522-526, 1986.

3. ASANO, Y.; YOSHIKAWA, T.; SUGA, S. et al. - Viremia and neutralizing antibody response in infants with exanthem subitum. J. Pediat., 114: 535-539, 1989.

4. ASANO, Y.; YOSHIKAWA, T.; SUGA, S. et al. - Enzyme-linked immunosorbent assay for detection of IgG antibody to human herpesvirus 6. J. med. Virol., 32: 119-123, 1990.
5. BIBERFELD, P.; PETRÉN, A.; EKLUND, A. et al. - Human herpesvirus-6 (HHV-6, HBLV) in sarcoidosis and lymphoproliferative disorders. J. virol. Meth., 21: 49-59, 1988.

6. BRIGGS, M.; FOX, J. \& TEDDER, R.S. - Age prevalence of antibody to human herpesvirus 6. Lancet, 1: 1058-1059, 1988.

7. BROWN, N.A.; SUMAYA, C.V.; LIU, C.R. et al. - Fall in human herpesvirus 6 seropositivity with age. Lancet, 2: 396, 1988.

8. CASERTA, M.T.; HALL, C.B.; SCHANABEL, K. et al. - Neuroinvasion and persistence of human herpesvirus 6 in children. J. infect. Dis., 170: 1586-1589, 1994.

9. CHERNESKY, M.A.; WYMAN, L; MAHONY, J.B. et al. - Clinical evaluation of the sensitivity and specificity of a commercially available enzyme immunoassay for detection of rubella virus- specific immunoglobulin M. J. clin. Microbiol., 20: 400404, 1984.

10. CONE, R.W.; HUANG, M.L.; ASHLEY, R. \& COREY, L. - Human herpesvirus 6 DNA in peripheral blood cells and saliva from immunocompetent individuals. J. clin. Microbiol., 31: 1262-1267, 1993.

11. DAHL, H.; LINDE, A.; SUNDQVIST, V. \& WAHREN, B. - An enzyme-linked immunosorbent assay for $\operatorname{IgG}$ antibodies to human herpes virus 6. J. virol. Meth., 29: $313-323,1990$

12. DEBYSER, Z.; REYNDERS, M.; GOUBAU, P. \& DESMYTE, J. - Comparative evaluation of three Elisa techniques and an indirect immunofluorescence assay for the serological diagnosis of Epstein-Barr virus infection. Clin. diagn. Virol., 8: 71-81, 1997.

13. DEWHURST, S.; McINTYRE, K.; SCHNABEL, K. \& HALL, C.B. - Human herpesvirus 6 (HHV-6) variant B accounts for the majority of symptomatic primary HHV-6 infections in population of US infants. J. clin. Microbiol., 31: 416-418, 1993.

14. DUBEDAT, S. \& KAPPAGODA, N. - Hepatitis due to human herpesvirus-6. Lancet, 2 : 1463-1464, 1989.

15. FOX, J.D.; BRIGGS, M.; WARD, P.A. \& TEDDER, R.S. - Human herpesvirus 6 in salivary glands. Lancet, 336: 590-593, 1990.

16. FREITAS, R.B.; LINHARES, M.I. \& LINHARES, A.C. - Prevalence of human herpesvirus 6 antibody among isolated Amazonian Amerindian communities in Brazil Trans. roy. Soc. trop. Med. Hyg., 88: 167-169, 1994

17. FREITAS, R.B. \& LINHARES, A.C. - Prevalence of human herpesvirus 6 antibody in the population of Belém, Pará, northern Brazil. Trans. roy. Soc. trop. Med. Hyg., 91: 538-540, 1997.

18. FREITAS, R.B.; LINHARES, A.C.; OLIVEIRA, C.S.; GUSMÃO, R.H. \& LINHARES, M.I. - Association of human herpesvirus 6 infection with exanthem subitum in Belém, Brazil. Rev. Inst. Med. trop. S. Paulo, 37: 489-492, 1995.

19. FRENKEL, N.; SCHIRMER, E.C.; WYATT, L.S. et al. - Isolation of a new herpesvirus from human CD4 ${ }^{+}$T cells. Proc. nat. Acad. Sci. (Wash.), 87: 748-752, 1990.

20. GOPAL, M.R.; THOMSON, B.J.; FOX, J.; TEDDER, R.S. \& HONESS, R.W. - Detection by PCR of HHV-6 and EBV DNA in blood and oropharynx of healthy adults and HIV- seropositives. Lancet, 335: 1598-1599, 1990.

21. HARNETT, G.B.; FARR, T.J.; PIETROBONI, G. R. \& BUCENS, M.R. - Frequent shedding of human herpesvirus 6 in saliva. J. med.Virol., 30: 128-130, 1990.

22. JAWETZ, E.; MELNICK, J.L. \& ADELBERG, E.A. - Antígeno e anticorpos. In: JAWETZ, E., ed. Microbiologia médica. Rio de Janeiro, Guanabara Koogan, 1970. p. 160.

23. JURETIC, M. - Exanthem subitum. A review of 243 cases. Helv. paediat. Acta, 1: 80 95, 1963.

24. KNOWLES, W.A. \& GARDNER, S.D. - High prevalence of antibody to human herpesvirus 6 and seroconversion associated with rash in two infants. Lancet, 2: 912-913, 1988. 
25. KOMAROFF, A.L. - Chronic fatigue syndrome: relationship to chronic viral infection. J. virol. Meth., 21: 3-10, 1988.

26. KONDO, K.; HAYAKAWA, Y.; MORI, H. et al. - Detection by polymerase chain reaction amplification of human herpesvirus 6 DNA in peripheral blood of patients with exanthem subitum. J. clin. Microbiol., 28: 970-974, 1990.

27. KONDO, K.; NAGAFUJI, H.; HATA, A.; TOMMORI, C. \& YAMANISHI, K. Association of human herpesvirus 6 infection of the central nervous system with recurrence of febrile convulsions. J. infect. Dis., 167: 1197-1200, 1993.

28. KRUEGER, G.R.; KOCH, B.; RAMON, A. et al. - Antibody prevalence to HBLV (human herpesvirus-6, HHV-6), and suggestive pathogenicity in the general population and in patients with immune deficiency syndromes. J. virol. Meth., 21: 125-131, 1988.

29. KRUEGER, G. R.; WASSERMANN, K.; DE CLERCK, L.S. et al . - Latent herpesvirus6 in salivary and bronchial glands. Lancet, 336: 1255-1256, 1990.

30. KUSUHARA, K.; UEDA, K.; MIYAZAKI, C.; OKADA, K. \& TOKUGAWA, K. - Attack rate of exanthem subitum in Japan. Lancet, 340: 482, 1992.

31. LAZZAROTO, T.; DALlA CASA, B.; CAMPISI, B. \& LANDINI, M.P. - Enzymelinked immunosobent assay for the detection of cytomegalovirus-IgM: comparison between eight commercial kits, immunofluorescence and immunoblotting. J. clin. Lab. Anal., 6: 216-218, 1992

32. LEVY, J.A.; FERRO, F.G.; GREENSPAN, D. \& LENNETTE, E. - Frequent isolation of HHV-6 from saliva and high seroprevalence of the virus in the population. Lancet, 335: $1047-1050,1990$

33. LINHARES, M.I.S.; EIZURU, Y.; TATENO, S. \& MINAMISHIMA, Y. - Seroprevalence of human herpesvirus-6 infection in Brazilian and Japanese populations in the Northeast of Brazil. Microbiol. Immunol., 35: 1023-1027, 1991.

34. LINNAVUORI, K.; PELTOLA, H. \& HOVI, T. - Serology versus clinical signs or symptoms and main laboratory findings in the diagnosis of exanthem subitum (roseola infantum). Pediatrics, 89: 103-106, 1992.

35. LUSSO, P.; SALAHUDDIN, S.Z.; ABLASHI, D.V. et al. - Diverse tropism of human B lymphotropic virus (human herpesvirus 6). Lancet, 2: 743-744, 1987.

36. LUSSO, P.; ENSOLI, B.; MARKHAM, P.D. et al. - Productive dual infection of human CD4+ T lymphocytes by HIV-1 and HHV-6. Nature (Lond.), 337: 370-373, 1989.

37. OKADA, K.; UEDA, K.; KUSUHARA, K. et al. - Exanthema subitum and human herpesvirus 6 infection: clinical observations in fifty-seven cases. Pediat. infect. Dis. J., 12: 204-208, 1993.

38. OKUNO, T.; TAKAHASHI, K.; BALACHANDRA, K. et al. - Seroepidemiology of human herpesvirus 6 infection in normal children and adults. J. clin. Microbiol., 27: 651-653, 1989.

39. OKUNO, T.; MUKAI, T.; BABA, K. et al. - Outbreak of exanthem subitum in an orphanage. J. Pediat., 119: 759-761, 1991.
40. OSMAN, H.K.; WELLS, C.; BABOONIAN, C. \& KANGRO, H.O. - Growth characteristics of human herpesvirus- 6 : comparison of antigen production in two cell lines. J. med. Virol., 39: 303-311, 1993.

41. PARKER, C.A. \& WEBER, J.M. - An enzyme-linked immunosorbent assay for the detection of $\mathrm{IgG}$ and $\mathrm{IgM}$ antibodies to human herpesvirus type 6. J. virol. Meth., 41: 265-276, 1993.

42. PORTOLANI, M.; CERMELLI, C.; MORONI, A. et al. - Human herpesvirus-6 infections in infants admitted to hospital. J. med. Virol., 39: 146-151, 1993.

43. PRUKSANANONDA, P.; HALL, C.B.; INSEL, R.A. et al. - Primary human herpesvirus 6 infection in young children. New Engl. J. Med., 326: 1445-1450, 1992.

44. ROSSIER, E.; MILLER, H.; McCULlOCH, B.; SULliVAN, L. \& WARD, K. Comparison of immunofluorescence and enzyme immunoassay for detection of measles-specific immunoglobulin M. J. clin. Microbiol., 29: 1069-1071, 1991.

45. SALAHUDDIN, S.Z.; ABLASHI, D.V.; MARKHAM, P.D. et al. - Isolation of a new virus, HBLV, in patients with lymphoproliferative disorders. Science, 234: 596-601, 1986

46. SAXINGER, C.; POLESKY, H.; EBY, N. et al. - Antibody reactivity with HBLV (HHV6) in U. S. populations. J. virol. Meth., 21: 199-208, 1988.

47. SCHIMER, E.C.; WYATT, L.S.; YAMANISHI, K.; RODRIGUEZ, W.J. \& FRENKEL, N. - Differentiation between two distinct classes of viruses now classified as human herpesvirus 6. Proc. nat. Acad. Sci. (Wash.), 88: 5922-5926, 1991.

48. SECCHIERO, P.; ZELLA, D.; CROWLEY, R.W.; GALLO, R.C. \& LUSSO, P. Quantitative PCR for human herpesvirus 6 and 7. J. clin. Microbiol., 33: 2124 2130,1995

49. SECCHIERO, P.; CARRIGAN, D.R.; ASANO,Y. et al. - Detection of human herpesvirus 6 in plasma of children with primary infection and immunosuppressed patients by polymerase chain reaction. J. infect. Dis., 171: 273-280, 1995.

50. SUGA, S.; YOSHIKAWA, T.; ASANO, Y.; YAZAKI, T. \& OZAKI, T. - Neutralizing antibody assay for human herpesvirus-6. J. med.Virol., 30: 14-19, 1990.

51. TAKAHASHI, K.; SONODA, S.; KAWAKAMI, K. et al. - Human herpesvirus 6 and exanthem subitum. Lancet, 1: 1463, 1988

52. UEDA, K.; KUSUHARA, K.; HIROSE, M. et al. - Exanthem subitum and antibody to human herpesvirus-6. J. infect. Dis., 159: 750-752, 1989.

53. YAMANISHI, K.; OKUNO, T.; SHIRAKI, K. et al. - Identification of human herpesvirus6 as a causal agent for exanthem subitum. Lancet, 1: 1065-1067, 1988.

54. YOSHIYAWA, H.; SUZUKI, E.; YOSHIDA, T.; KAJII, T. \& YAMAMOTO, N. - Role of human herpesvirus 6 infection in infants with exanthem subitum. Pediat. infect. Dis. J., 9: 71-74, 1990.

Received: 15 May 2000

Accepted: 10 July 2000 